\section{Some Observations on Byssus Thread in Juveniles of the Hard Clam Meretrix lamarckii}

Jun-ichi Narihara* and Yasuharu Morisue* (Received March 6, 1991)

A number of settling juveniles of the hard clam Meretrix lamarckii (Japanese name: chosen-hamaguri), have been investigated since 1969 by the Miyazaki Prefectural Fisheries Experimental Station for conservation of its fisheries resources in the shallow waters of the Okuragahama and Kanegahama regions of Hyuga City, Miyazaki Prefecture.

Among the juveniles collected in 1989 and 1990, specimens having a transparent thread-like structure on the foot were found (Fig. 1, A and B). In a histological examination it was recognized that the structure was a byssus thread secreted from a byssal gland in the foot. This would be the first observation of the byssus thread and the byssal gland in $M$. lamarckii.

The present specimens were collected in the tidal zone along the coast of the Okuragahama region every month from April 1989 to February 1990. Specimens having the byssus thread were found every month at a rate of about 4 to $25 \%$ of the total specimens. Shell length (S.L.) of all the specimens measured was from 1.3 to $10.0 \mathrm{~mm}$, while that of the specimens with the thread was from 1.3 to $5.5 \mathrm{~mm}$. The length of the thread varied individually. The longest one was about three times longer than its shell length. The thickness of the threads was about $40 \mu \mathrm{m}$ in specimens of 2 to $3 \mathrm{~mm}$ in S.L.

Several specimens with the thread were examined histologically. Successive $5 \mu \mathrm{m}$ sections of soft bodies were stained with the usual hematoxylin-eosin method. The thread stained purple had no fibrous structure and originated in a winding glandular duct which was lined with a single epithelial cell layer within the muscular tissue of the foot (Fig. 1, C and D). The blind end of the duct was near the central part of body and closed to the mid-gut gland and the intestine. Its opposite end opened at the centroabdominal edge of the foot (Fig. 1, B and D). Juveniles smaller than about $5 \mathrm{~mm}$ in S.L. had glandular ducts with openings

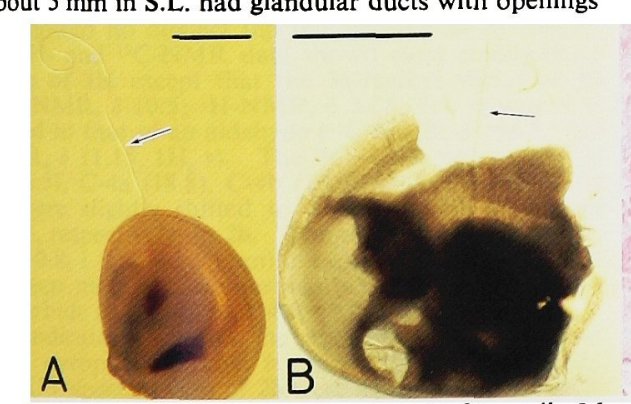

and contained threads or developing threads within the cavity (Fig. 1, D). This was also found in the juveniles in which threads were not seen from the outside of the shells. However, the glandular duct lost the opening to the outside of the shell in juveniles of about $10 \mathrm{~mm}$ in S.L.

From the observations it seems that the byssal gland secrets the byssus thread when $M$. lamarckii is smaller than about $5 \mathrm{~mm}$ in S.L., the gland degenerates and the byssus thread is lost by specimens with a size of about $10 \mathrm{~mm}$ in S.L.

The byssal gland and byssus thread are restricted to the larval or juvenile stages in several bivalves including species of Pecten, Anodonta, Tapes $(=$ Ruditapes), Nucula and $M y a .^{1-4)}$ It is reported that species with feet adapted for burrowing have vestigial foot glands which produce the byssus thread. ${ }^{3)}$ Juveniles of Ruditapes philippinarum generally use the attach themselves to sand grains and stones, ${ }^{2)}$ and the young of Mya arenaria also attach themselves byssally to weeds or stones. ${ }^{4)}$ The byssus thread of $M$. lamarckii might have a similar role as Barnes ${ }^{5)}$ states: "For the (bivalve) larvae of many unattached burrowing forms produce a byssus (thread) for initial temporary anchorage on settling." However, as its juveniles have a byssus thread up to $5 \mathrm{~mm}$ in S.L. after settling, it may also have another role in keeping the body in the sand bed against movements of the waves. It is considered that the survival rate in the juvenile stage is influenced by the stability of the body in the sand bed. We should study how the byssus thread contributes to stabilizing the body in the sand bed.

\section{References}

1) S. Shiino: Suisan Musekitsui Dobutsugaku, 8th ed., Baifukan, Tokyo, 1985, pp. 178-201.

2) H. Yoshida: J. Simonoseki Coll. Fish., 3, 1106 (1953)

3) Ll. D. Gruffydd, D. J. W. Lane, and A. R. Beaumont: J. Mar. Biol. Assoc. U.K., 55, 463476 (1975)

4) C. M. Yonge: J. Mar. Biol. Assoc. U.K., 42, 113-125 (1962).

5) R. D. Barnes: Invertebrate Zoology, 4th ed., Holt-Saunders Japan, Tokyo, 1980, pp. 408-416.

Fig. 1. Byssus and byssal gland of juvenile Meretrix lamarckii.

A: External view of a shell. Scale bar is $1 \mathrm{~mm}$.

B: Left side view of the soft body without valves. Scale bar is $1 \mathrm{~mm}$.

C: A byssal gland lined with a single epithelial cell layer (E). Scale bar is $50 \mu \mathrm{m}$.

D: A tissue section of a foot stained with hematoxylin and eosin (H.E.). A byssal gland (G) within the muscular tissue (M) of the foot. Its blind end is close to the digestive tract (D). A cavity of the glandular duct contains the thread or developing thread (B). Scale bar is $0.5 \mathrm{~mm}$.

* Miyazaki Prefectural Fisheries Experimental Station, Aoshima, Miyazaki 889-22, Japan (成原淳一, 森末 保治：宮崎県水産試験場)。 